\title{
KEEFEKTIFAN ORGANISASI PERGURUAN TINGGI \\ (Studi Kasus Pada Universitas Muhammadiyah Palangkaraya)
}

\author{
SONEDI \\ Dosen Pada FKIP Universitas Muhammadiyah Palangkaraya
}

\begin{abstract}
ABSTRAK
Penelitian ini bertujuan untuk mendeskripsikan keefektifan organisasi Universitas Muhammadiyah Palangkaraya dilihat dari segi efisiensi dan produktivitas, dan mendeskripsikan kemampuan adaptasi dan pengembangan organisasi Universitas Muhammadiyah Palangkaraya

Temuan-temuan hasil penelitian menunjukan bahwa: 1) Untuk mencapai efisiensi dan produktivitas ditempuh langkah-langkah: perumusan tujuan yang hendak dicapai, penentuan bidang atau unit sebagai bagian yang akan melaksanakan pencapaian tujuan, menetapkan jangka waktu yang diperlukan, menetapkan metode mencapai tujuan, menetapkan alat yang dapat digunakan untuk mencapai tujuan. Dengan langkah-langkah tersebut Universitas Muhammadiyah Palangkaraya mampu menghasilkan out put sesuai target yang telah ditentukan baik secara kuantitatif maupunh secara kualitatif. 2) Kemampuan adaptasi dan pengembangan Universitas Muhammadiyah palangkaraya, dilihat dari upaya-upaya yang dilakukan pimpinan dalam mengatasi masalah atau tantangan baik secara internal maupun eksternal, sehingga universitas ini masih tetap eksist dan berkembang sesuai dengan harapan masyarakat, walaupun faktor dana menjadi kunci pengembangan universitas. Berdasarkan data temuan sesuai fokus penelitian, maka dapat ditarik kesimpulan bahwa organisasi perguruan tinggi Muhammadiyah Palangkaraya adalah efektif.
\end{abstract}

Kata kunci: Efektivitas, organisasi, perguruan tinggi

\begin{abstract}
This research aims at describing the effectifity of Universty of Muhammadiyah Palangkaraya organization that is seen from the efficiency and productivity sides and describing the ability of adaptation and development of University of Muhammadiyah Palangkaraya organization.

The findings of research result showed that: 1) to reach the effectifity and productivity were done the steps: reaching of the formulation of purpose, the determination the field or unit as the section that will do the purpose attainment, deciding the phase of time that was needed, deciding the instrument that could be used to reach the purpose. By the steps University of Muhammdiyah Palangkaraya could produce the out put approriate the target given both quantitaitive and qualitative. 2) The ability of adaptation and development of University of Muhammadiyah Palangkaraya, they were seen from the efforts from the leader in overcoming the problem or challenge both internal and external, so this university still keep exist and developing accord with society expectation, although the donation factor became the key of university development. Based on the data accord with the research focus, so it could be concluded that the organization of college of Muhammadiyah Palangkaraya was effective.
\end{abstract}

Key words: Effectiveness, organization, college

\section{PENDAHULUAN}

Era globalisasi yang penuh tantangan telah menimbulkan persaingan antar bangsa semakin tajam terutama dalam bidang ekonomi dan bidang ilmu pengetahuan serta teknologi. Dalam rangka menghadapi persaingan yang semakin sulit dan agar dapat berperan serta dalam pembangunan bangsa dan negara maka perguruan tinggi melalui Direktorat Jenderal, Dikti Depdiknas mencanangkan Higher Education Long Term Strategy (HELTS 2003 - 2010) dalam tiga kebijakan dan program pendidikan tinggi, yaitu: (1). pemerataan dan perluasan akses; (2) peningkatan mutu, relevansi dan daya saing; (3) 
penguatan tata kelola, akuntabilitas, dan pencitraan publik.

Berdasarkan pada kebijakan dan program tersebut, proses pembelajaran merupakan esensi dari penyelenggaraan pendidikan di perguruan tinggi. Peningkatan kualitas, efektifitas, efisiensi, produktivitas merupakan aspek-aspek mutlak yang harus dipenuhi demi mewujudkan suatu visi suatu perguruan tinggi. Paradigma baru manajemen pendidikan tinggi menekankan pentingnya otonomi institusi yang berlandaskan pada akuntabilitas, evaluasi, dan akreditasi dan bermuara pada tujuan akhir peningkatan kualitas secara berkelanjutan. Di pihak lain, kecenderungan globalisasi, kebutuhan masyarakat dan tuntutan persaingan yang semakin ketat menuntut komitmen yang tinggi pada penyelenggaraan pendidikan yang bermutu.

Pemahaman tersebut, bahwa mengubah wajah pendidikan merupakan satu perubahan paradigma pengelolaan pendidikan yang memerlukan pergeseran arah dan kebijakan dalam berbagai aspek dan dimensi yang saling terkait. Paradigma lama yang sangat cendrung kearah pencapaian targer kuantitatif, harus digeser keparadigma baru yang lebih difokuskan pada pencapaian sekaligus peningkatan mutu pendidikan khususnya mutu lulusan. Untuk itu diperlukan suatu kemauan dan komitmen dari semua pihak yang diwujudkan dengan tindakan nyata dan secara konsisten dipertahankan kesinambungannya. Penerapan strategi perubahan manajemen pendidikan di perguruan tinggi harus dilaksanakan secara profesional, sistemik, sinergik, dan simbolik dari semua pihak terkait.
Pendidikan tinggi hendaknya diselenggarakan dengan menggunakan prinsipprinsip manajemen yang fleksibel dan dinamis agar memungkinkan setiap perguruan tinggi untuk berkembang sesuai dengan potensinya masingmasing dan tuntutan eksternal yang dihadapinya. Manajemen sering diartikan sebagai ilmu, kiat/seni, dan profesi. Luther Gulick mengatakan manajemen sebagai ilmu, karena manajemen dipandang sebagai suatu bidang pengetahuan yang secara sistematik berusaha memahami mengapa dan bagaimana orang bekerjasama. Follet, mengatakan sebagai kiat/seni, karena manajemen mencapai sasaran melalui cara-cara dengan mengatur orang lain menjalankan dalam tugas. Disisi lain manajemen, dipandang sebagai profesi karena manajemen dilandasi oleh keahlian khusus untuk mencapai suatu prestasi manajer, dan para profesional dituntut oleh suatu kode untuk mencapai tujuan tertentu yang telah dirumuskan sebelumnya.

Shrode dan Voich (dalam Fattah, 1999) menyatakan bahwa tujuan utama manajemen adalah produktivitas dan kepuasaan. Tujuan ini tidak tunggal bahkan jamak atau rangkap, seperti peningkatan mutu pendidian. Untuk mencapai tujuan utama manajemen tersebut diperlukan pengelolaan yang efektif.

Efektivitas organisasi yang tinggi sangat diperlukan dalam setiap usaha kerja sama pegawai untuk mencapai tujuan organisasi, yang seperti kita ketahui bahwa pencapaian tujuan organisasi ini adalah sesuatu yang diidamidamkan oleh setiap organisasi. Hal ini sesuai dengan pernyataan Martoyo (2000), efektivitas yaitu suatu kondisi atau keadaan, di mana dalam memilih tujuan yang hendak dicapai dan sarana 
atau peralatan yang digunakan, disertai dengan kemampuan yang dimiliki adalah tepat, sehingga tujuan yang diinginkan dapat dicapai dengan hasil yang memuaskan. Tetapi sebaliknya dengan organisasi yang memiliki efektivitas organisasi yang rendah akan sangat sukar mencapai hasilhasil yang baik.

Scheerens (1991) istilah efektif sering dikaitkan dengan kualitas pendidikan. Kemudian Sander dan Wiggins (1985) menyatakan bahwa efentivitas telah menjadi salah satu paradigma administrasi pendidikan. Dengan demikian dapatlah disimpulkan bahwa untuk mendapatkan mutu pendidikan yang diharapkan di suatu lembaga pendidikan, maka dipandang penting menelaah secara mendalam masalah efektivitas organisasi atau lembaga pendidikan.

Efektivitas organisasi termasuk organisasi pendidikan, terdapat perbedaan pendapat dari para ahli tentang kreteria efektivitas organisasi. Menurut Lipham, Renkin, \& Hoeh (1985) menyatakan keefektivan organisasi termasuk perguruan tinggi dapat diukur melalui prestasi dan pemeliharaan organisasi.

Saran dan Trafford

mengemukakan tujuh kreteria untuk menentukan efektivitas organisasi perguruan tinggi, yaitu: 1) kepemimpinan, 2) iklim organisasi, 3) keterampilan-keterampilan dasar akademik, 4) harapan dan kinerja mahasiswa, 5) misi organisasi, 6) strategi motivasi, dan 7) umpan balik terhadap kinerja akademik.

Hoy dan Miskel (1987) mengemukakan bahwa efektivitas organisasi dapat dilihat dari dua segi yaitu: 1) the goal model, dan 2) the system resource model. Kedua model tersebut masingmasing mempunyai kreteria untuk dapat menentukan keefektifan suatu organisasi. Streers (1985) menyatakan bahwa keefektifan organisasi dapat dilihat dari empat kreteria yaitu: 1) karakteristik organisasi, 2) karakteristik lingkungan, 3) karakteristik pekerjaan, dan 4) kebijakan dan praktik manajemen.

Penelitian ini menetapkan dua pendekatan yaitu 1) Pendekatan pencapaian tujuan meliputi: Efisiensi/produktivitas. 2) pendekatan sistem, yang dibatasi pada kemampuan adaptasi lingkungan dan pengembangan. Kedua pendekatan inilah yang dijadikan dasar untuk menilai apakah organisasi dalam perguruan tinggi, dalam hal ini Universitas Muhammadiyah Palangkaraya yang dijadikan obyek penelitian, efektif dalam menjalaankan visi dan misinya.

Fokus penelitiannya adalah 1) bagaimana keefektifan organisasi Universitas Muhammadiyah Palangkaraya dengan kriteria efisiensi dan produktivitas?; 2) bagaimana kemampuan organisasi Universitas Muhammadiyah Palangkaraya dengan kriteria kemampuan adaptasi dan pengembangannya?

Gibson, dkk (1992) menyatakan bahwa pengorganisasian meliputi semua kegiatan manajerial yang dilakukan untuk mewujudkan kegiatan tang direncanakan menjadi suatu struktur tugas, wewenang dan menentukan siapa yang akan melaksanakan tugas tertentu untuk mencapai hasil yang diinginkan organisasi.

Berdasarkan pendapat tersebut, dapat dipahami dalah satu prinsip pengorganisasian adalah pembagian tugas ke dalam berbagai unsur organisasi. Dengan kata lain pengorganisasian yang efektif adalah membagi habis dan 
menstrukturkan tugas-tugas ke dalam sub-sub atau komponen-komponen organisasi.

Dalam pengorganisasian bukan hanya mengidentifikasi jabatan dan menentukan hubungan, namun yang paling penting adalah mempertimbangkan dan memperhatikan kebutuhan orang-orang atau karyawan agar berfungsi dengan baik. Sejalan dengan hal tersebut Koontz, O'Donnel, \& Weihrich (1990) mengemukakan bahwa pengorganisasian adalah penetapan struktur peran internal dalam suatu lembaga yang terorganisasi secara formal.

Sergiovanni (1987: 315) mengatakan for competing requirements for organizing thet should be considered are legitimacy, efficiency, effectiveness, and exelence. Pendapat tersebut menggambarkan bahwa ada empat syarat yang harus dipertimbangkan dalam pengorganisasian yaitu legitimasi, efisiensi, efentivitas dan keunggulan.

Pengorganisasian yang efektif menurut Gibson, dkk (1992) membutuhkan ide yang realistis dan jelas atas tingkah laku orang dalam organisasi, mengacu pada pengalaman dan pedoman tugas-tugas yang telah ditetapkan. Struktur organisasi yang berkaitan erat dengan teknologi yahg digunakan, seyogyanya disiapkan atau disesuaikan dengan sumberdaya manusianya. Demikian juga sikap saling mempercayai dan saling melengkapi dalasm organisasi dapat menciptakan suasana penuh harapan dan diyakini banwa semua program dapat dilaksanakan dengan baik untuk mencapai tingkat prestasi yang tinggi. Kepercayaan ini menunjukan bahwa sasaraqn tugas, pelaksanaan tugas, tanggung jawab, penggunaan alat yang diperlukan, pengalokasian waktu, dana dan sumber daya adalah sebagai implementasi keefektifan pengorganisasian dari elemen-elemen yang diperlukan di dalam organisasi efektif.

Berdasarkan uraian di atas dapat disimpulkan bahwa pengorganisasian adalah tindakan pimpinan organisasi dalam melaksanakan kegiatan manajer untuk mewujudkan hasil yang direncanakan dengan menentukan sasaran, struktur tugas, wewenang dan tanggungjawab. Menentukan fungsi-fungsi setiap personil dalam melaksanakan tugas pada berbagai unsur organisasi, menentukan alat-alat yang diperlukan, pengalokasian waktu, dana dan sumberdaya yang lain. Sebagai organisasi, perguruan tinggi paling tidak memiliki empat komponen utama, yaitu (1) adanya tujuan, (2) adanya aktivitas untuk mencapai tujuan, (3) adanya kerja sama atau keikut sertaan orang lain, dan (4) adanya pemimpin organisasi yang memiliki posisi sentral dalam organisasi.

Stoner dan Winkel (1986) menyebutkan kegiatan dengan istilah kegiatan organisasional Artinya kegiatan untuk mencapai tujuan suatu lembaga pendidikan tinggi tidak hanya dilakukan sendiri oleh pimpinan, tetapi bersama-sama dengan staf (dosen dan karyawan) secara efektif.

Strategi manajemen organisasi lembaga pendidikan tinggi (perguruan tinggi) pada umumnya bertolak dari kebijakan dasar pendidikan tinggi yang titetapkan. Gibson, dkk (1992) mengatakan dua jenis pola kebijaksanaan dasar pendidikan tinggi yaitu (a) pola yang lebih berorientasi pada kemajuan ilmu pengetahuan dan teknologi (the edvancement of knowledge an technology), (b) pola yang lebih berorientasi pada kemajuan pendidikan (the edvancement of education). 
Seperti halnya dikemukakan Arthur G. Gedeian, dkk (1991:61) adalah That is, the greater the extent it which an organization's goals are met or surpassed, the greater its effectiveness (semakin besar pencapaian tujuan-tujuan organisasi semakin besar efektivitas). Selanjutnya Arthur G. Gedeian, dkk (1991:66) mengatakan : That is, an organization's long-run success hinges upon its ability to establish and maintain a favorable input-output ratio (organisasi akan bertahan jika dapat pemasukan lebih besar dari yang dituntut untuk pengeluaran). Hal ini berarti bahwa efektivitas organisasi dapat dilihat dari besarnya pencapaian tujuan dan besarnya output.

Efektivitas merupakan salah satu konsep yang memiliki arti penting bagi suatu organisasi perguruan tinggi. Koontz (1990) mengemukakan bahwa keefektifan menunjuk kepada pencapaian tujuan yang diinginkan, untuk menghasilkan akibat yang diinginkan. Lebih lanjut Gie (1985) Mengungkapkan bahwa efektivitas berasal dari kata efektif, yang berarti terjadinya sesuatu efek atau akibat yang dikehendaki dalam suatu perbuatan atau pekerjaan. Suatu pekerjaan atau kegiatan dikatakan efektif jika mencapai tujuan khusus atau perilaku sesuai dengan harapan birokrasi untuk peran yang ada (Hoy \& Miskel, 1987). Efektivitas organisasi (organizational effectiveness) merupakan suatu konsep multi dimensional dan sebagai suatu fenomena unidimensional (Sergiovanni, 1991). Sementara keefektifan organisasi merupakan suatu fenomena beraneka segi (multi faceted phenomenon) (Holdway \& Jonhson dalam Creemers \& Reynolds, 1993).

Bernard (dalam Gibson, dkk. 1992) menjelaskan bahwa efektivitas organisasi adalah keberhasilah mencapai tujuan yang ditetapkan dengan usaha kerja sama. Hall (1974) menyatakan efektivitas organisasi adalah sejauh mana suatu organisasi merealisasikan tujuantujuannya yang telah ditetapkan. Lebih jelas lagi Gibson, dkk. (1992) mengemukakan bahwa efektivitas organisasi merupakan konsep yang sangat luas, mencakup sejumlah komponen konsep baik jangka pendek seperti produksi efisiensi, dan kepuasan. Jangka menengah seperti menyesuaikan diri (adaptiveness), dan pengembangan (development). Jangka panjang suatu organisasi kemampuannya untuk bertahan hidup. Sementara Hoy dan Miskel (1987) mengatakan bahwa efektifitas organisasi merupakan suatu fenomena yang meliputi multi dimensional, terdiri dari komponen-komponen adaptasi dari kuantitas, kualitas dari produk, pencapaian mahasiswa yang lebih tinggi, sistem tujuan yang terintegrasi, dan kesamaran yang dapat menuntun penyeleksian terhadap indicatorindikator efektivitas.

Scheerens (1997) mengemukakan bahwa produktifitas, output efektif dari proses utama, haruslah di pandang sebagai dimensi aktual dari keefektifan. Alternatif kriteria keefektifan, seperti kemampuan beradaptasi dengan lingkungan, kepuasan akan pekerjaan, konsensus dan kontinuitas yang di garansi oleh struktur yang telah terbentuk, dapat dikatakan sebagai "alat" atau perantara pencapaian tujuan. Lebih lanjut Scheerens memberikan contoh dalam konteks pendidikan, dapat di lihat sebagi dari kriteria "kemepuan beradaptasi (adaptability)", ukuran yang spesifik (specific measures), instrument dan pola yang terorganisasi untuk menjadikan 
kurikulum lebih relevan dengan kebutuhan pasar kerja (labour market).

Robbins (1990:53) mengklasifikasikan empat pendekatan dalam mempelajari efektifitas organisasi, yaitu: a) Pendekatan Pencapaian Tujuan (The Goal Attainment Approach). Pendekatan ini menunjukkan bahwa suatu efektifitas organisasi dinilai lebih pada kaitannya dengan tujuan akhir daripada dengan prosesnya. Kriteria yang umum digunakan dalam pendekatan ini adalah maksimasi laba. Dengan demikian asumsi yang digunakan dalam pendekatan ini seluruh kriteria yang digunakan harus dapat diukur (measureable); b) Pendekatan Sistem (The System Approach). Pendekatan ini tidak menekankan pada tujuan akhir tetapi memasukkan seluruh kriteria dalam satu element dan masing-masing akan saling berinteraksi. Pendekatan sistem ini menekankan pada kelangsungan hidup organisasi untuk jangka waktu panjang. c) Pendekatan Konstituen Strategis (The Strategic-Constituencies).

Pendekatan ini menunjukkan bahwa organisasi yang efektif adalah organisasi yang dapat memuaskan keinginan para konstituen dalam lingkungannya. Masing-masing konstituen tersebut mempunyai keinginan yang berbedabeda. Pemilik berkeinginan untuk memperoleh return on investment yang tinggi, karyawan akan menginginkan kompensasi yang memadai, pelanggan menginginkan kemampuan membayar hutang, demikian juga dengan pihak-pihak lainnya akan mempunyai keinginan yang unik; d) Pendekatan nilai-nilai persaingan (The Competing-Value Approach). Pendekatan ini menawarkan suatu kerangka yang lebih integrative dan lebih variatif, karena kriteria yang dipilih dan digunakan tergantung pada posisi dan kepentingan masing-masing dalam suatu organisasi. Sehubungan dengan tingkat variatif yang relative tinggi, maka terdapat tiga perangkat dasar nilai-nilai, yaitu: 1) fleksibilitas versus pengendalian, 2) manusia versus organisasi, 3) proses versus tujuan akhir. Berdasarkan tiga perangkat dasar tersebut dapat digambarkan empat model nilai-nilai efektivitas, yaitu human rational model, open system model, rational goal model dan internal process model sebagaimana yang disajikan dalam gambar. 1 
HUMAN RELATION MODEL

OPEN SISTEM MODEL

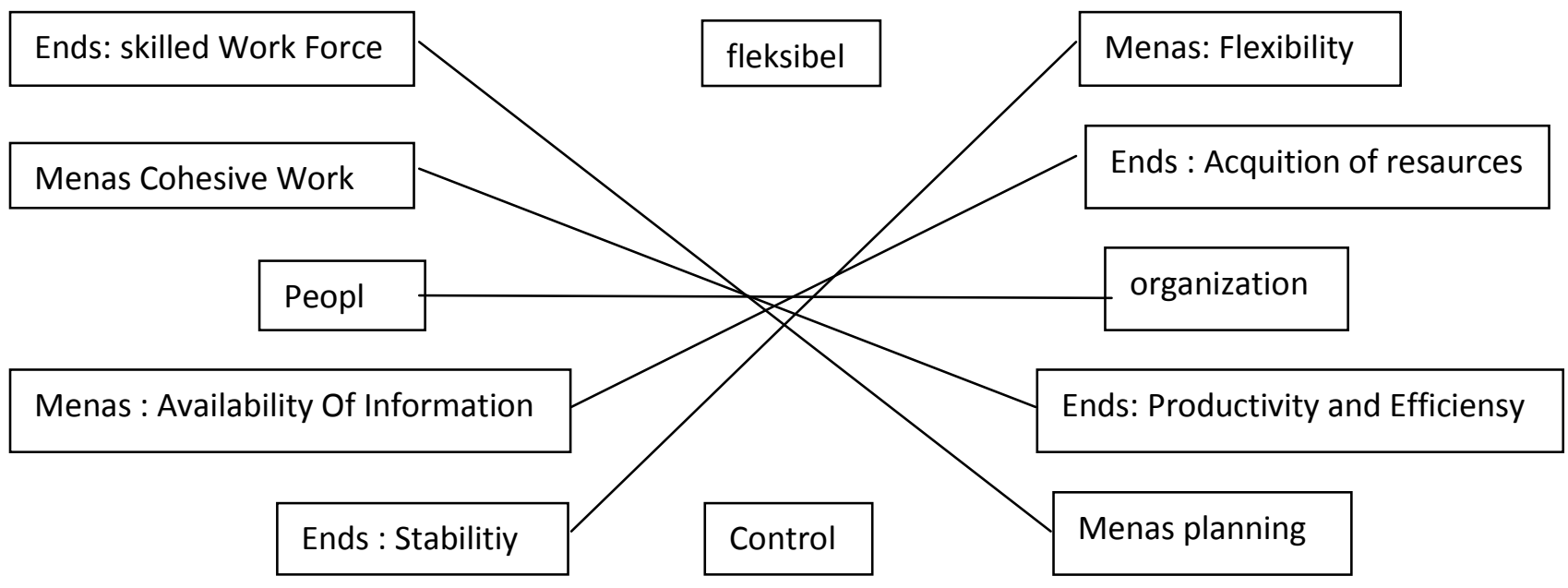

INTERNAL PROCESS MODEL

RATIONAL GOAL MODEL

Gambar 1. Model nilai-nilai Efektitas diadopsi dari Robbins 1990:72

Dari beberapa pendapat di atas, pendekatan efektivitas organisasi yang digunakan dalam penelitian ini, mengacu pada pendekatan yang digunakan Gibson, dkk (1992) yaitu: 1) pendekatan pencapaian tujuan, dengan membatasi pada kriteria efisiensi dan produktivitas, 2) pendekatan sistem dengan membatasi pada kriteria kemampuan adaptasi dan pengembangan organisasi.

\section{METODE}

Pengamatan mendalam dalam latar penelitian dan situasi yang wajar, yang dikenal sebagai pendekatan kualitatif atau naturalistik, dimana situasi akan tetap bersifat natural, alamiah, wajar dan tidak ada tindakan manipulasi, pengaturan ataupun eksperimen (Bogdan dan Biklen, 1982). Penelitian ini menggunakan rancangan studi kasus, hal ini sesuai dengan pernyataan Yin (1987) memberikan batasan yang lebih bersifat teknis dengan penekanan pada ciricirinya yaitu studi kasus adalah suatu inkuiri empiris yang menyelidiki fenomena di dalam konteks kehidupan nyata, bilamana: batasanbatasan antara fenomena dan konteks tidak tampak dengan tegas, dan di mana: multisumber bukti dimanfaatkan.

Penelitian ini menggunakan pendekatan kualitatif yang menjadi alat utama adalah manusia (human tool) artinya peneliti sendiri sebagai instrumen (key instrument) (Bogdan dan Biklen, 1982; Raharjo, 2003; Muhajir, 2000). Kehadiran peneliti di lokasi penelitian untuk meningkatkan intensitas peneliti berinteraksi dengan sumber data guna mendapatkan informasi yang lebih valid dan abash tentang fokus penelitian.

Penelitian dilaksanakan di Universitas Muhammadiyah Palangkaraya. Alasan dipilinnya Universitas Muhammadiyah Palangkaraya sebagai tempat penelitian didasarkan pada keunikan, menarik dan merupakan Universitas Muhammadiyah yang ada di Kalimantan Tengah yang menjadi tanggungjawab kepemilikan melalui 
Pimpinan Pusat Majelis Pendidikan Tinggi Muhammadiyah. Secara operasional tanggungjawab diserahkan kepada Badan Pembina Harian (BPH) yang diwakili oleh Pimpinan Wilayah Muhammadiyah Kalimantan Tengah.

Milles dan Hubermen (1992) menyatakan bahwa dalam menggunakan snowball sampling technique yaitu untuk mencari informan secara terus menerus dari informan satu ke informan lain, sehingga data dapat diperoleh semakin banyak dan mendalam. Sedangkan Guba dan Lincoln (1985) mengatakan bahwa seorang yang dijadikan informan kunci hendaknya memiliki pengetahuan dan informasi atau dekat dengan situasi yang terjadi difokus penelitian. Informan kunci dalam penelitian ini adalah rektor, pembantu rektor, kepala BAAK, kepala BAU dan BPH di lingkungan universitas.
Teknik pengumpulan data yang sesuai dan relevan dengan fokus dan tujuan penelitian, maka dilakukakan dengan menggunakan tiga teknik yaitu: (1) wawancara mendalam (indepth interviewing), (2) observasi partisipasi (participant observation), dan (3) Studi Dokumen (study of document) (Bogdan dan Biklen, 1982). Milles \& Huberman (1992) yaitu melalui tiga alur (1) reduksi data, (2) penyajian data, dan (3) penarikan kesimpulan/verifikasi data. Ketiga langkah ini merupakan alur analisis untuk membuat data menjadi bermakna. Ketiganya merupakan satu kesatuan dan proses yang saling berulang secara interaktif serta dilakukan selama dan sesudah pengumpulan data.

Teknik analisis data dengan model analisis interaktif (Miles \& Hambermen, 1992) seperti pada gambar berikut.

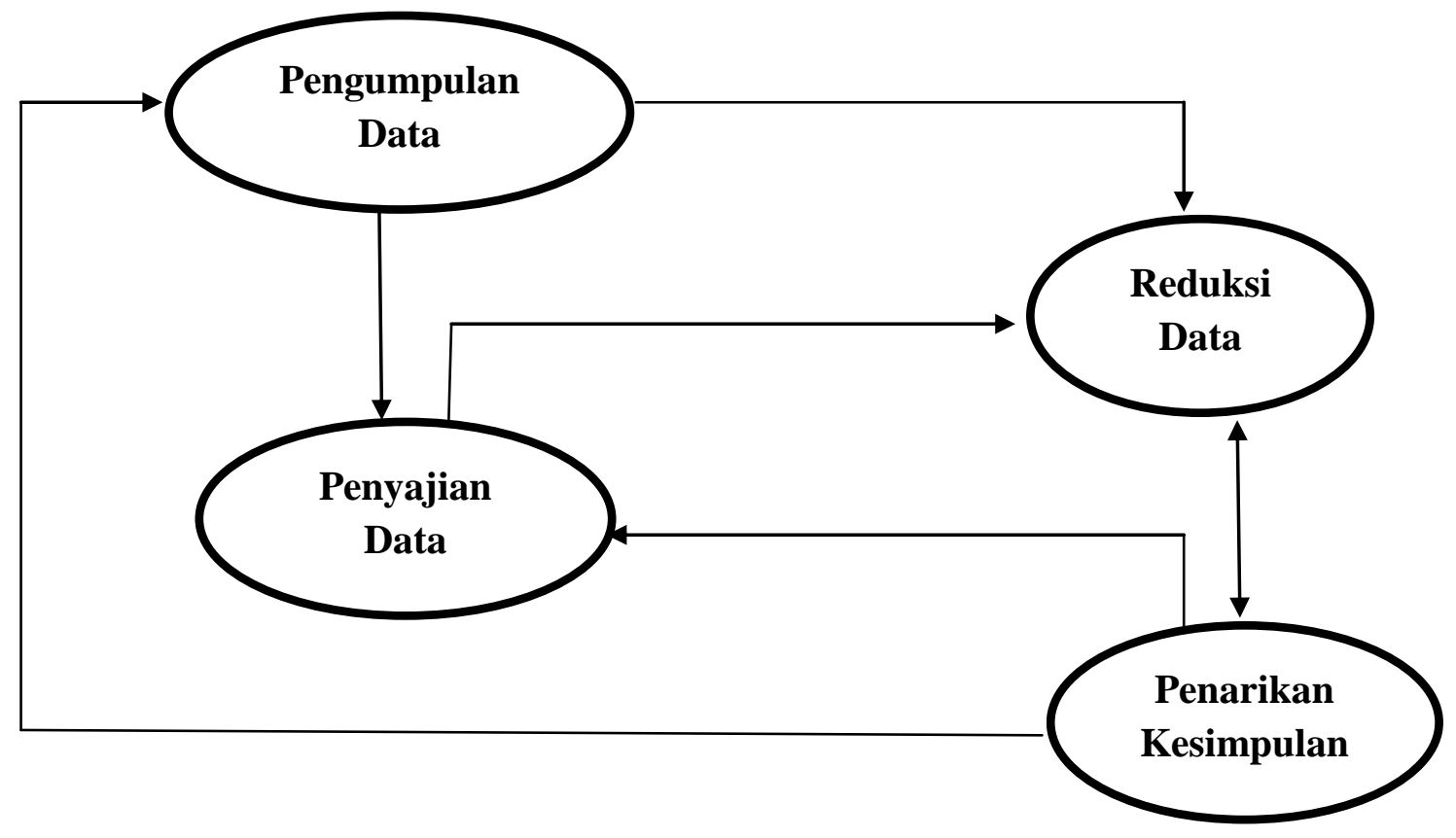

Gambar.2. Analisis data model interaktif diadopsi dari Miles \& Hambermen, 1992 


\section{TEMUAN PENELITIAN DAN PEMBAHASAN}

Efisiensi dalam organisasi tidak lepas dari pembicaraan mengenai pencapaikan tujuan. Memang, kebanyakan rumusan mengenai efisiensi dalam organisasi akhirnya terkait pada masalah seberapa berhasilnya suatu organisasi mencapai sasaran dan tujuan yang dibuat. Artinya, pencapaian tujuan suatu organisasi secara efektif tidak bisa mengabaikan masalah efisiensi. Karena pentingnya arti efisiensi untuk mencapai tujuan suatu organisasi secara efektif, maka tinjauan mengenai efisiensi dalam organisasi Universitas Muhammadiyah Palangkaraya berdasarkan data yang diperoleh dapat dilihat pada matrik 1 berikut ini:

Matrik 1. Efisiensi Dan Produktivitas dilihat dari Efektivitas Organisasi Universitas Muhammadiyah Palangkaraya

\begin{tabular}{|c|c|}
\hline Komponen & Keadaan \\
\hline $\begin{array}{l}\text { Efisiensi Dan Produktivitas } \\
\text { Dilihat Dari Efektivitas } \\
\text { Organisasi Universitas } \\
\text { Muhammadiyah } \\
\text { Palangkaraya }\end{array}$ & $\begin{array}{l}\text { Dalam melakukan efisiensi, pimpinan UM Palangkaraya menempuh cara: } \\
\text { merumuskan tujuan yang hendak dicapai, menentukan fungsi unit } \\
\text { sebagai bagian-bagian yang akan melaksanakan kegiuatan pencapaian } \\
\text { tujuan, menetapkan jangka waktu pencapaian tujuan, menetapkan } \\
\text { metode pencapaian tujuan, menetapkan alat yang diperlukan. Datanya } \\
\text { sebagai berikut: } \\
\text { Tujuan pendidikan UM Palangkaraya: } \\
\text { 1. Menyiapkan peserta didik menjadi anggota masyarakat yang memiliki } \\
\text { kemampuan akademik dan professional yang beriman dan bertaqwa } \\
\text { kepada Allah SWT, berakhlaq mulia dan berwawasan Negara } \\
\text { kesatuan Republik Indonesia. } \\
\text { 2. Mengembangkan dan melakukan inovasi iptek, kesenian dan } \\
\text { kebudayaan yang dijiwai oleh nilai-nilai Islam serta sesuai dengan } \\
\text { kebutuhan pembangunan daerah maupun nasional } \\
\text { 3. Melakukan pencerahan, memperluas wawasan, memperkokoh nilai- } \\
\text { nilai kemanusiaan, akhlaqul karimah, etika yang bersumber pada } \\
\text { ajaran Islam serta memupuk keikhlasan dalam melaksanakan amal } \\
\text { ma'ruf nahi munkar } \\
\text { 4. Mewujudkan lulusan yang bermutu, beriman, dan bertaqwa kepada } \\
\text { Allah SWT, berakhlaq mulia, cakap, mandiri, berguna bagi } \\
\text { masyarakat dan Negara yang dapat dibanggakan baik dari segi } \\
\text { akhlaq, profesi, kemandirian, maupun masyarakat dan Negara. } \\
\text { (Doc.I.1./sond/2009) } \\
\text { Agar tujuan tersebut tepat, maka prosesnya merupakan hasil analisis } \\
\text { data yang diproyeksikan ke masa depan dalam bentuk harapan-harapan } \\
\text { yang diusahakan untuk dapat dicapai dengan melakukan langkah- } \\
\text { langkah kegiatan: 1) merumuskan tujuan-tujuan khusus yang lebih } \\
\text { spesifik sehingga semakin jelas aspek-aspek yang hendak dicapai, 2) } \\
\text { menetapkan tatacara pelaksanaannya yang berpedoman pada undang- } \\
\text { undang, peraturan pemerintah yang berlaku, statuta universitas dan } \\
\text { aturan pimpinan universitas muhammadiyah palangkaraya atas } \\
\text { persetujuan Pimpinan Wilayah Kalimantan Tengah dalam hal ini BPH } \\
\text { yang ditunjuk. (W/sond/B/02/2009) }\end{array}$ \\
\hline
\end{tabular}




\begin{tabular}{|c|c|}
\hline Komponen & Keadaan \\
\hline 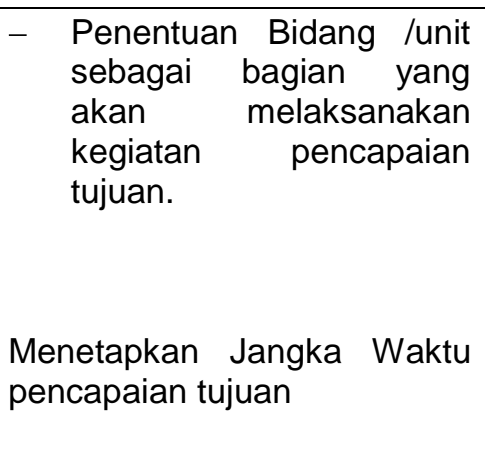 & $\begin{array}{l}\text { Wewenang, fungsi, tugas pokok dan tanggung jawab dibagi sesuai } \\
\text { dengan bidang/unit yang ada yaitu: Badan penyelenggara, Badan } \\
\text { Pelaksana Harian, Badan Penyantun, Semat Universitas, Pimpinan } \\
\text { Universitas Unsur-Unsur Fakultas, Dosen, Biro akademik dan } \\
\text { kemakasiswaan, Biro administrasi Umum, LP2M, dan Unit pelaksana } \\
\text { teknis Universitas Muhammadiyah palangkaraya. (D.II.1/sond/bau/2009) } \\
\text {...karena kami memperhitungkan efisiensi, maka seluruh kegiatan } \\
\text { operasional dalam rangka pencapaian tujuan penetapan jangka waktunya } \\
\text { kami pikirkan dan perhitungkan secara cermat. (W/sond/J/01/2009) }\end{array}$ \\
\hline $\begin{array}{ll}- & \text { Menetapkan metode } \\
\text { pencapaian tujuan }\end{array}$ & $\begin{array}{l}\text {... kami selalu menekankan kepada seluruh staf baik dosen maupun } \\
\text { karyawan dan tenaga teknisi yang lain agar bekerja secara baik dan } \\
\text { sungguh-sungguh sehingga dapat menciptakan hasil yang optimal baik } \\
\text { dari segi kualitas maupun kuantitas. Sesuai dengan kemampuan yang } \\
\text { dimiliki Universitas Muhammadiyah, maka cara kerja yang selalu kami } \\
\text { tekankan adalah: 1) cara kerja yang paling mudah atau cara yang } \\
\text { sederhana dalam arti tidak sulit dipikirkan, } 2 \text { ) Cara yang paling ringan; } 3 \text { ) } \\
\text { cara yang cepat dan tepat, karena dengan menggunakan waktu yang } \\
\text { sedikit lebih baik dari pada menggunakan waktu yang banyak dengan } \\
\text { hasil yang sama; 4) cara yang paling murah dan tidak boros dalam } \\
\text { pemakaian biaya; 5) cara yang tidak menimbulkan resiko yang } \\
\text { merugikan. Jadi prinsipnya bekerja dengan menggunakan pikiran, } \\
\text { tenaga, waktu, dan dana seekonomis mungkin, namun dapat mencapai } \\
\text { hasil yang memuaskan. (W/Sond/J/01/2009) } \\
\text { Dalam melaksanakan tugas-tugas universitas Muhammadiyah selalu } \\
\text { berpedoman pada tata cara yang telah digariskan oleh pimpinan yaitu } \\
\text { cara kerja yang mudah, cepat, dan berusaha melakukan penghematan. } \\
\text { Oleh sebab itu disini banyak menggunakan instrument-instrumen yang } \\
\text { dibuat berdasarkan kreteria kinerja yang dilakukan sivitas akademika. } \\
\text { (W/sond/S/03/2009) } \\
\text {...pada umumnya banyak dosen yang menggunakan metode ceramah } \\
\text { dan diskusi kelas serta memberikan tugas kepada mahasiswa dianggap } \\
\text { paling mudah dilaksanakan, disamping itu keterbatasan fasilitas belajar, } \\
\text { terutama buku-buku wajib dan sumber belajar yang dimiliki oleh } \\
\text { Universitas Muhammadiyah Palangkaraya, maka kami anggap hal itulah } \\
\text { yang paling tepat dan cukup efisien. (W/sond/B/02/2009) }\end{array}$ \\
\hline $\begin{array}{l}\text { Menetapkan } \\
\text { diperlukan }\end{array}$ & $\begin{array}{l}\text {... Usaha pengadaannya dilakukan berdasarkan kesepakatan bersama } \\
\text { agar memungkinkan pelaksanaannya lebih baik dan dapat } \\
\text { dipertanggungjawabkan, baik dari segi kualitas maupun kuantitas setelah } \\
\text { mempertimbangkan secara matang mengenai jumlah dana yang tersedia. } \\
\text { Oleh karena dana yang tersedia sangat terbatas, maka penetapan alat } \\
\text { yang diperlukan didasarkan pada prinsip bahwa: } 1 \text { ) alat pada dasarnya } \\
\text { merupakan sumber kerja yang patut dipergunakan apabila mampu untuk } \\
\text { meningkatkan hasil yang dapat dicapai dibandingkan dengan cara kerja } \\
\text { tanpa menggunakan alat; } 2 \text { ) alat itu tepat, artinya harus sesuai dengan } \\
\text { kemampuan personil yang akan menggunakannya; } 3 \text { ) penetapan alat } \\
\text { sesuai dengan kebutuhan; } 4 \text { ) alat sifatnya primer. (W/sond/S/03/2009) }\end{array}$ \\
\hline
\end{tabular}




\begin{tabular}{|c|c|}
\hline Komponen & Keadaan \\
\hline $\begin{array}{l}\text { Rasio perbandingan antara } \\
\text { input dan output }\end{array}$ & $\begin{array}{l}\text { Agaknya sulit untuk menentukan secara akurat dan matematis mengenai } \\
\text { rasio perbandingan antara input dan output karena bervariasinya waktu } \\
\text { yang digunakan oleh setiap mahasiswa dalam melaksanakan masa } \\
\text { study. Ada yang tepat menggunakan waktu minimal delapan semester } \\
\text { atau sekitar empat tahun, ada yang lima tahun, ada yang enam, dan } \\
\text { bahkan ada yang menggunakan waktu maksimal yaitu sampai empaat } \\
\text { belas semester atau sekitas tujuh tahun. Penyebabnya cukup beralasan } \\
\text { antara lain: karena fantor ekonomi, faktor kebanyakan mahasiswa } \\
\text { bekerja sambil kuliah, faktor kesulitan menyelesaikan karya tulis ilmiah } \\
\text { (skripsi untuk program sarjana), faktor keluarga, faktor kesibukan } \\
\text { mengurus organisasi. Di sinilah letak kesulitannya, karena perguruan } \\
\text { tinggi tidak memproduksi barang atau benda mati. Jadi menurut saya } \\
\text { kesulitan semacam ini dialami oleh semua lembaga pendidikan tinggi. } \\
\text { Tetapi kami tetap berusaha melakukan efisiensi dengan cara } \\
\text { menggerakkan semua sumberdaya secara ekonomis dan berdaya guna, } \\
\text { mengadakan target pada sasaran yang ingin dicapai. (W/sond/B/02/2009) } \\
\text { Bila dilihat dari prospek nilai tambah intelektual dan moral yang diperoleh } \\
\text { keluaran Universitas Muhammadiyah Palangkaraya ini, dengan apa yang } \\
\text { diinvestasikan dalam proses pendidikan mereka, menurut saya kita telah } \\
\text { meraih keuntungan yang jauh lebih besar. Kalau rasio perbandingan } \\
\text { antara input dan output kita melihatnay dari sudut pandang upaya-upaya } \\
\text { Universiyas Muhammadiyah Palangkaraya dalam memcapai tujuan } \\
\text { melalui siklus input-proses-output sangat efisien dan } \\
\text { produktif.(W/sond/FF/03/2009) }\end{array}$ \\
\hline
\end{tabular}

Kemampuan adaptasi dan pengembangan adalah kesungguhan organisasi melakukan perubahan sesuai dengan tuntutan keadaan, serta kemampuan organisasi melihat ke depan, melakukan investasi dalam rangka mempertahankan hidup dan mengembangkan usahanya. Semua organisasi, tidak terkecuali organisasi perguruan tinggi semantiasa dihadapkan pada berbagai tantangan secara terus menerus yang menuntut kemampuan perguruan tinggi itu untuk menjawab tantangantantangan itu dengan sebaik-baiknya agar tidak berkembang menjadi masalah dan hambatan yang berdampak negative yang pada akhirnya membawa kerugian besar bahkan menyebankan kematian sebuah perguruan tinggi.
Berdasarkan data diperoleh, maka dapat disimpulkan bahwa organisasi Universitas Muhammadiyah Palangkaraya adalah efektif bila dilihat dari kemampuan adaptasi dan pengembangan yang dicapai hingga saat ini. Agar mudah dipahami, maka seluruh data yang telah dipaparkan dituangkan ke dalam matrik 2 sebagai berikut. 
Matrik 2 Efektivitas Organisasi Universitas Muhammadiyah Palangkaraya dengan Kriteria Kemampuan Adaptasi dan Pengembangan

\begin{tabular}{|c|c|}
\hline Komponen & Keadaan \\
\hline 1. Kemampuan Adaptasi & $\begin{array}{l}\text { Tantangan yang dihadapi dan kesanggupan melakukan perubahan } \\
\text { sesuai dengan tuntutan sejak berdirinya pada tahun } 1987 \text { sampai dengan } \\
\text { tahun } 1997 \text {. Berikut paparan datanya: } \\
\text { Pada tahun } 1987 \text { sampai dengan } 1997 \text { tantangan yang dihadapi oleh } \\
\text { universitas muhammadiyah palangkaraya dari faktor internal berupa fisik } \\
\text { adalah: sarana prasarana terutama gedung kuliah, perpustakaan, } \\
\text { laboratorium, serta peralatan kantor; dana yang dari dulu sampai } \\
\text { sekarang bahkan yang akan datang menjadi hal yang terpenting ; } \\
\text { Gedung kuliah masih menggunakan gedung bersama dengan SMA } \\
\text { Muhammadiyah dan SMP Muhammadiyah. Berupa non fisik adalah } \\
\text { kualitas tenaga karyawan dan dosen, terutama dosen tetap yang rata- } \\
\text { rata masih berkualifikasi sarjana (S1); kualitas kelembagaan, } \\
\text { pengembangan ilmu pengetahuan dan teknologi, gelombang perubagan } \\
\text { globalisasi, tekanan ekonomi dan sosial politik. } \\
\text { Upaya-upaya yang dilakukan dalam mengatasi tantangan-tantangan } \\
\text { tersebut antara lain: 1) ....mem-bangun gedung perkuliahan , gedung } \\
\text { perpustakaan, laboratorium, dan peralatan-peralatan yang dibutuhkan } \\
\text { baik yang berhubungan dengan kegiatan operasional kependidikan } \\
\text { maupun yang berhubungan dengan kegiatan operasional administratif; } 2 \text { ) } \\
\text {.. menggalang partisifasi masya-rakat terutama warga muhammadiyah } \\
\text { yang senantiasa memberikan dukungan terhadap keberlangsungan hidup } \\
\text { universitas ini sebagai salah satu amal usaha persyarikatan } \\
\text { muhammadiyah; 3) Meningkatkan kualitas karyawan,...; } 4 \text { ) Mening-katkan } \\
\text { kualitas dosen...; 5) Meningkatkan kualitas kelembagaan dengan } \\
\text { menambah fakultas, program studi, mengembangkan kurikulumsesuai } \\
\text { tuntutan perkembangan ilmu pengetahuan dan teknologi, tuntutan } \\
\text { masyarakat, melakukan evaluasi diri pada setiap program studi agar } \\
\text { status akreditasinya bisa meningkat melalui Badan Akreditasi Nasional } \\
\text { Perguruan Tinggi; } 6 \text { ) meningkatkan kualitas pelayanan dan pembinaan } \\
\text { mahasiswa. }\end{array}$ \\
\hline 2. Pengembangan & $\begin{array}{l}\text { Perbandingan keadaan masa lalu dangan masa sekarang serta upaya } \\
\text { UM palangkaraya untuk masa yang akan datang. Paparan datanya: } \\
\text { Kalau kita menelusuri sejarah perkembangan Universitas Muhammadiyah } \\
\text { Palangkaraya sejak berdirinya hingga saat ini, maka kita dapat } \\
\text { mengatakan bahwa universitas ini mampu beradaptasi dan berkembang, } \\
\text { disadari atau tidak perkembangannya sangat baik bila dibandingkan } \\
\text { dengan beberapa perguruan tinggi swasta yang lain yang seumur dengan } \\
\text { Universitas Muhammadiyah Palangkaraya. Bukti kemampuan tersebut } \\
\text { adalah eksistensinya sekarang yang mampu berkembang dan mampu } \\
\text { mengembangkan diri sesuai dengan harapan masyarakat pengguna } \\
\text { jasanya, bahkan jauh berbeda dari keadaanya dulu. } \\
\text { (W/sond/bph/M/07/2009). }\end{array}$ \\
\hline
\end{tabular}




\begin{tabular}{|c|c|}
\hline Komponen & Keadaan \\
\hline & $\begin{array}{l}\text { Agar Universitas Muhammadiyah Palangkaraya tetap bisa berjalan, } \\
\text { bahkan bisa lebih maju dari apa yang dicapai sekarang ini, maka telah } \\
\text { dibuat rencana pengembanganuntuk jangka } 10 \text { tahun mendatang } \\
\text { (periode tahun } 2007-2017 \text { ) yang meliputi: } 1 \text { ) meningkatkan kualitas } \\
\text { akademik yang dititik beratkan pada peningkatan kualitas kurikulum, } \\
\text { peningkatan kualitas pendidikan dan pengajaran, peningkaatan kualitas } \\
\text { penelitian dan pengabdian pada masyarakat, peningkaatan kualitas } \\
\text { keluaran; 2) Peningkatan kualitas kelembagaan yang dititik beratkan } \\
\text { pada peningkatan kualitas sumberdaya manusia Staf, karyawan dan } \\
\text { dosen), Penyempurnaan dan pemantapan organisasi dan administrasi, } \\
\text { penyempurnaan sisten dan prosedur kerja, peningkatan jumlah dan mutu } \\
\text { tenaga administrasi sesuai kebutuhan; 3) Peningkatan kualitas } \\
\text { pembinaan kemahasiswaan; 4) peningkatan/pengembangan sarana } \\
\text { prasarana yang menitik berapkan pada pembangunan gedung kuliah, } \\
\text { ruangan perpustakaan, ruangan administrasi, ruangan dosen, ruangan } \\
\text { staf ahli, ruangan laboratorium dan peralatan lainnya yang sangat } \\
\text { dibutuhkan; 5) peningkatan kualitas pengelolaan keuangan. } \\
\text { (W/sond/J/01/2009). }\end{array}$ \\
\hline
\end{tabular}

Berdasarkan data yang didapatkan di lapangan, maka akan dikemukakan temuantemuan penelitian sebagai jawaban permasalahan penelitian. Temuan yang dimaksud dikemukakan berdasarkan pada dua hal pokok yakni:1 ) efektivitas organisasi Universitas Muhammadiyah Palangkaraya dengan criteria efisiensi dan produktivitas, 2) efektivitas organisasi Universitas Muhammadiyah Palangkaraya dengan criteria kemampuan adaptasi dan pengembangan.

1. Efektivitas organisasi Universitas Muhammadiyah Palangkaraya dengan kriteria efisiensi dan produktivitas

Data yang diperoleh menunjukan bahwa organisasi Universitas Muhammadiyah Palangkaraya dilihat dari segi efisiensi dan produktivitas adalah efektif. Hal tersebut didapat dari data bahwa terdapat beberapa cara Universitas Muhammadiyah melakukan tindakan efisiensi dan memdorong produktivitas yaitu: a) merumuskan tujuan yang ingin dicapai secara tegas, b) menentukan bidang/fungsi/unit sebagai bagian-bagian yang akan dilaksanakan kegiatannya untuk mencapai tujuan, 3) menetapkan jangka waktuyang diperlukan dalam segala aktivitas untuk mencapai tujuan, 4) menetapkan alat yang dapat dipergunakan untuk meningkatkan efisiensi dan produktivitas pencapaian tujuan, 5) menetapkan jumlah dan sumber dana yang diperlukan.

Sehubungan dengan hal tersebut Nawawi (1981) menyatakan bahwa alat pada dasarnya merupakan sumber kerja material yang dapat diadakan untuk meningkatkan efisiensi dan produktivitas pencapaian tujuan. Soedjadi mengatakan bahwa azas efisiensi itu mutlak perlu, oleh karena itu salah satu faktor yang sangat penting diperhatikan adalah pengadaan, pendayagunaan, pengendalian peralatan haruslkah dilakukan dengan efektif dan efisien pula. Siagian (2003)

2. Efektivitas organisasi Universitas Muhammadiyah Palangkaraya dengan kriteria kemampuan adaptasi dan pengembangan 
Berdasarkan kriteria ini data yang diperoleh dalam penelitian menunjukan; a) Kemampuan Universitas Muhammadiyah Palangkaraya mengatasi tantangan-tantangan dan melakukan perubahan sesuai dengan tuntutan keadaan, b) kemampuan Universitas Muhammadiyah Palangkaraya memandang jauh ke depan dan melakukan investasi dalam rangka mempertahankan hidup dan mengembangkan usaha pendidikan. Berdasarkan paparan data mengenai kriteria kemampuan adaptasi dan pengembangan ini dapat disimpulkan bahwa organisasi Universitas Muhammadiyah Palangkaraya adalah efektif. Sehubungan dengan hal tersebut Chester I. Bernard (dalam Gibson, dkk, 1992: 27) menyatakan bahwa efektivitas adalah pencapaian tujuan dan sasaran yang telah disepakati atau usaha bersama.

\section{PENUTUP}

1. Terdapat beberapa langkah dalam menciptakan efisiensi untuk mendorong produktivitas pencapaian tujuan pada Universitas Muhammadiyah Palangkaraya yaitu: a) merumuskan dan menetapkan tujuan yang hendak dicapai, b) menentukan bidang/unit sebagai bagian-bagian yang akan dilaksanakan kegiatannya untuk mencapai tujuan, c) menetapkan jangka waktu yang diperlukan, d) menetapkan alat yang dapat dipergunakan untuk meningkatkan efisiensi dan produktivitas. Dilihat dari efisiensi dan produktivitas yang dicapai, dimana rasio perbandingan antara input (seluruh investasi sumberdaya) dan output yang dicapai baik dari segi kualitas (bersifat material) yakni tercapainya target yang ditetapkan, maupun dari segi kualitas (bersifat inmaterial) yakni nilai tambah manusiawi, intelektual, keimanan dan ketaqwaan, serta moral/akhlak mulia yang merupakan nilai keuntungan yang jauh lebih besar, maka organisasi Universitas Muhammadiyah Palangkaraya adalah efektif.

2. Sejak berdirinya tahun 1987 sampai sekarang tantangan yang dihadapi Universitas Muhammadiyah Palangkaraya adalah: a) Dari faktor internal berupa fisik yakni sarana prasarana. Non fisik yakni kualitas tenaga yang masih terbatas, kualitas kelembagaan, dan kualitas keluaran; b) dari faktor eksternal seperti perkembangan IPTEK, gelombang perubahan arus globalisasi, krisis ekonomi, sosial politik dan budaya. Untuk mengatasi tantangan tersebut, pimpinan Universitas Muhammadiyah Palangkaraya berupaya keras, sistematis, dan berencana mengintensifkan penggalangan daya dukung dari mahasiswa, persyarikatan, pemerintah dan masyarakat disamping melakukan efisiensi pada setiap kegiatan sehingga sedikit demi sedikit mengalami perkembangan yang cukup baik. Kemampuan adaptasi dan pengembangan Universitas Muhammadiyah Palangkaraya nampak pada perbedaan keadaan awal berdirinya dan keadaan sekarang. Keadaan tersebut menunjukan organisasi Universitas Muhammadiyah Palangkaraya adalah efektif.

Sedangkan saran yang diberikan berdasarkan hasil penelitian adalah sebagai berikut:

1. Melaksanakan tugas sesuai dengan fungsi dan kewenangan dan tanggungjawab yang dilengkapi kemampuan atau pengetahuan teoretik yang lebih baik dan lebih berhasil 
dibandingkan melaksanakan tugas-tugas hanya dengan mengandalkan potensi alamiah, tanpa pengetahuan teoretik. Berdasarkan asumsi ini, maka disarankan terutama kepada para pemimpin Universitas Muhammadiyah Palangkaraya agar memperhatikan dan melengkapi diri, melengkapi seluruh anggota dengan pengetahuan keorganisasian, manajemen pendidikan terutama manajemen perguruan tinggi sebagai modal untuk lebih meningkatkan efektivitas dan lebih mengembangkan universitas ini di masamasa yang akan datang.

2. Efektivitas sebaiknya dipandang sebagai proses yang berkesinambungan dan bukan sebagai keadaan akhir. Menggerakkan, mengarahkan, mengontrol, dan mempertahankan usaha yang mengarah kepada pencapaian tujuan secara efisien dan produktif merupakan tugas yang tidak pernah selesai bagi para pemimpin. Oleh sebab itu disarankan kepada pemimpin universitas agar tetap mempertahankan, bahkan lebih meningkatkan lagi upaya-upaya yang telah dilakukan selama ini agar Universitas Muhammadiyah Palangkaraya lebih efektif lagi.

3. Sehubungan dengan keterbatasan ketenagaan (baik dosen maupun karyawan) masih merupakan tantangan dan masalah yang cukup serius bagi Universitas Muhammadiyah Palangkaraya, maka disarankan bagi pimpinan agar tetap memotivasi dan membantu pendanaan bagi dosen untuk melanjutkan studi pada jenjang yang lebih tinggi, dan memprioritaskan program-program latihan bagi pengembangan karyawan.

\section{UCAPAN TERIMA KASIH}

Peneliti mengucapkan terimakasih yang sebesar-besarnya kepada pimpinan di lingkungan Universitas Muhammadiyah Palangkaraya, mitra bertari yang telah berkenan membaca, mengoreksi, secara cermat dan memberikan perbaikan pada tulisan ini, teman sejawat sebagai mitra diskusi dalam penelitian ini, dan redaktur yang telah memberikan saran dan kritikan demi perbaikan tulisan ini.

\section{DAFTAR PUSTAKA}

Bogdan, R.C., \& Biklen, S.K. 1982. Qualitative Research for Education: An Introduction to Theory and Methods. ( $3^{\text {rd }}$ Edition), Boston: Allyn and Bacon, Inc.

Fattah, N. 1999, Landasan Manajemen Pendidikan. Bandung: Remaja Rosda Karya.

Gibson., Ivancevick., \& Donnely, J.R. 1992.Organization and Management: Behavior, Structure, Process.Plano: Business Publication

Guba, E.G., \& Lincoln, Y.S. 1985. Effective Evaluation: Improving the Usefulness of Evaluation Result Through Responsive and Naturalistiv Approaches. San Fransisco, California: Jossey-Bass Inc., Publishers.

Hoy, W.K., \& Miskel. C.G. 1987. Educational Administration: Theory, Research, and Practice $\left(3^{\text {rd }}\right.$ Ed.). New York: Random House, Inc.

Koontz, H., O'Donnel, C., \& Weihrich, H. 1990. Manajemen. Terjemahan oleh Hutahuruk, G. Jakarta: Erlangga.

Lipham, J.M., Rankin, R.E., \& Hoeh, J.A., Jr. (1985). The Principalship: oncepts, Competencies, and Cases. New York: Logman, Inc. 
Miles, B.M., \& Heiberman, A.M. 1992. Qualitative Data Analysis: A Source Book of New Methouds. Beverley Hills: Sage Publication, Inc.

Muhadjir, N. 2000. Metodologi Penelitian Kualitatif. (4 edisi). Yogyakarta: Rake Sarusin.

Raharjo, M.P. 2003. Metode Riset Kualitatif. Salatiga: UKSW.

Robbin, S. P. 1990, Organization Theory, Structure, Design, and Application. thiird edition, USA: Prentice Hall, Inc.

Saran, R., \& Trafford, V. 1990. Research in Education Management and Policy: Retrospect and Prospect. London, New York: The Falmer Press.

Scheerens, J., \& Bosker, R. 1997. The Foundations of Educational Effectiveness. New York: Elsevier Science Inc.

Sergiovanni, T.J. 1987. Educational Governance and Administration. New Yersey:Prentice Hall, Inc.

Steers, R.M. 1985. Efektivitas Organisasi. Terjemahan oleh. Jamin Magdalena. Jakarta Erlangga.

Stoner, J.A., \& Winkel,C. 1986. Management. New Yersey: Prentice Hall, Inc

Gie, T.L. 1985. Ensikopedia Administrasi. Jakarta: CV. Masagung, MCML

Yin, R.K. 2002. Studi Kasus Desain dan Metode. Terjemahan oleh M. Djuazi Mudzakir. Jakarta: PT Raja Grafindo Persada. 